DOI: 10.15587/2312-8372.2019.184253

\section{Boiko 0., Zozulynets V., Ivanychko $\mathbf{V}$, Kovalchuk $\mathbf{0}$.}

\title{
ALKALI ACTIVATED CONCRETES MIX DESIGN USING RED MUD AS AN ACTIVE AGGREGATE
}

Об’єктом дослідження є склад лужних бетонів загальнобудівельного призначення з використанням червоного шламу алюмінієвого виробництва як активного заповнювача. Основною проблемою при роботі з червоним шламом є його хімічний склад та висока питома поверхня, які доволі негативно впливають на властивості будівельний матеріалів.

В ході дослідження використовувалися сучасні методи фізико-хімічного аналізу для отримання результатів. Визначення фізико-механічних та спечіальних (мічність, морозостійкість, карбонізачія, корозійна стійкість, радіаційна стійкість, довговічність, власні деформацї̈ усадки) властивостей досліджуваних бетонних сумімей та лужних бетонів з високим вмістом червоного шламу здійснювалось за стандартними методиками згідно з чинними нормативами. Також брався до уваги світовий досвід по роботі з червоним шламом.

Отримано оптимальні показники функціональних властивостей бетонів з використанням червоного шламу, що дозволяє стверджувати про довговічність та екологічність такого матеріалу. Це пов'язано з тим, що надійність іммобілізацї лужних бетонів відповідає вимогам стандарту, а ще засвідчує, що розроблені бетони $\epsilon$ безпечними для навколишнього середовища.

Було проведено дослідження радіаційної стійкості лужних бетонів на основі червоного шламу та визначено, що даний бетон зі вмістом шламу в кількості до 40 \% (від маси бетону) відноситься до I класу за класифікацією будівельних матеріалів і може бути використаний для всіх видів будівництва без обмежень.

Завдяки цьому забезпечується можливість розширення номенклатури будівельних матеріалів та отримання абсолютно нового виробу, виготовленого на основі техногенної сировини, що значно знижує ціну і підвищує попит на продукцію. Особливо у порівнянні з іншими подібними виробами, виготовленими на природній сировині.

Ключові слова: лужний иемент, лужний бетон, червоний шлам, техногенний продукт промисловості, індекс активних конщентращій, важкі метали.

Received date: 14.06 .2019

Accepted date: 10.07 .2019

Published date: 31.10 .2019
Copyright (c) 2019, Boiko O., Zozulynets V., Ivanychko V., Kovalchuk O. This is an open access article under the CC BY license (http://creativecommons.org/licenses/by/4.0)

\section{Introduction}

Due to the rapid development of the global industrial sector and scientific and technological progress, the problem of recycling related products and industrial waste arises. The amount of waste that has formed can't be completely disposed of for its specific chemical composition. Therefore, as a rule, a significant amount of waste is stored near factories in huge areas (slurries), which occupy large areas. Most of the iron-containing accompanying products of the industry contain a number of heavy metals; during long-term storage, they become soluble and pose an environmental threat to the environment. That is why the problem arises of the disposal of such related industrial products in the production of building materials.

Red mud is one of the main representatives of the ironcontaining industrial products of the industry. However, modern concepts of obtaining traditional building materials do not allow to utilize it to a large extent through a variable chemical composition. That's why the solution to this issue is relevant by obtaining new concrete based on alkaline cements using red mud. After all, alkaline cements make it possible to utilize a significant amount of iron-containing waste while maintaining or improving the operational characteristics of artificial stone, not inferior to traditional binders.

The utilization of red mud in alkaline concrete and their further implementation requires a study of the functional properties of artificial stone, taking into account the influence of the different nature of the main part of the care. As well as the effects of the type of alkaline component and environmental safety assessment of the resulting material for the environment.

\section{The object of research and its technological audit}

The object of research is the composition of alkaline concrete for general construction using red mud from aluminum production as an active aggregate.

The main problem when working with red mud is its chemical composition and high specific surface, which quite negatively affect the properties of building materials. That's why the content of red mud in the component composition is quite limited, which does not allow to completely utilize this industry care.

To determine the maximum allowable content of red mud in concrete, it is necessary to analyze its effect on the 
basic properties of concrete and to study the degree of harmful effect of this concrete on the environment. At the same time, one should pay attention to immobilize ability, proper shrinkage deformations and the process of carbonization of alkaline concrete with a high content of red mud.

\section{The aim and objectives of research}

The aim of research is determination of the properties of concrete based on red mud, their durability and the feasibility of application while ensuring high environmental safety of the environment.

To achieve this aim it is necessary to solve the following objectives:

1. To study the effect of red mud on the durability of alkaline concrete.

2. To determine the effect of the percentage of red mud in the system on the frost resistance of artificial stone.

3. To investigate natural shrinkage strain of alkaline concrete with a high content of red mud.

4. To investigate the carbonation process of alkaline concrete with a high content of red mud.

5. To investigate the radiological properties of alkaline concrete using red mud.

\section{Research of existing solutions of the problem}

The rapid development of the world economy and the influence of scientific and technological progress lead to constantly growing production capacities of the industrial sector. The increase in production requires the use of an increasing raw material base and leads to a deterioration in the state of non-renewable natural resources due to the rapid plowing of stocks and damage to the environment.

Related industrial products and waste are an integral part of production, the complexity of disposal of which is explained by their rather diverse nature.

Warehousing of red mud on large spaces in muds and natural depressions is quite dangerous. So, the global accumulation of red mud is about 2.7 Gt. However, each year its amount increases by $120 \mathrm{Mt}$ [1], which entails a number of problems associated with the constant costs of its safe storage or processing.

In $[2,3]$, the technological feasibility of using red mud in blast furnace smelting as iron-containing additives was shown. However, in addition to iron, which is mainly $\mathrm{Fe}_{2} \mathrm{O}_{3}$, they contain up to $15-20 \% \mathrm{Al}_{2} \mathrm{O}_{3}$, and the $\mathrm{CaO} / \mathrm{SiO}_{2}$ ratio is close to unity. In addition, red mud is about $4-5 \% \mathrm{MgO}$.

Studies [4, 5] demonstrate the possibility of using dry residues of red mud for the production of soot iron and metal-carbon compositions.

The wider use of red mud is limited due to its chemical and particle size distribution. Alumina waste is represented by fine powder. Granulometric composition and its specific surface depend on three main factors:

1) fineness of grinding bauxite;

2) chemical dispersion of its shares in the process of autoclave leaching;

3) aggregation of mud particles during washing and thickening under the influence of coagulants and flocculants.

The phase and mineral compositions of red mud are determined by its mineralogical characteristics [6].
As a rule, red mud is dusty and clay particles that are prone to aggregation, so the actual dispersed composition may vary. In the practice of processing most varieties of bauxite according to the Bayer method, it is crushed to a particle size of $0.063 \mathrm{~mm}$. Large fractions of dispersed mud (1000-50 microns) are mainly represented by quartz and iron-containing phases, and the fraction of 100-250 microns consists of quartz, hematite, calcite; in the fraction of 50-100 microns, hematite, alumohematite prevail; fraction of $10-50 \mu \mathrm{m}$ - hematite, alumohematite, alumogoethite; the content of hydrogarnets increases [7, 8]. Fine fractions (less than 10 microns) are hydroaluminosilicates (alkaline and aluminate sodalites, nosean or cancrinite), hydrogarnets, carbonates, alumogoethite, dispersed hematite, silica, rutile. For small fractions, alkalis are predominant in the composition with a small amount of iron-containing phases.

The results of studies of mud from more than 60 enterprises of various industries of Ukraine show that a significant variation in the composition of mud requires differentiation in processing technologies. At the same time, the presence of a significant amount of non-ferrous metals allows to conclude that their burial is inexpedient $[9,10]$.

Thus, the analysis results allow to conclude that red mud can be used as active aggregates in alkaline concrete. It is the matrix of alkaline cement that will compensate for the disadvantages of red mud, such as high specific surface area, alkalinity and reactivity.

\section{Methods of research}

Experimental results were obtained using a complex of modern methods of physicochemical analysis: X-ray phase (XRD), differential thermal (DTA), and scanning electron microscopy. X-ray phase analysis was carried out on a DRON-3M and DRON-4-07 diffractometer (Russian Federation) with a copper tube at a voltage of $30 \mathrm{kV}$, a current of $10 \ldots 20 \mathrm{~mA}$ and an angle range of $2 \theta=10 \ldots 60^{\circ}$ at a counter rotation speed of $2^{\circ}$ per minute. Differentialthermal and thermogravimetric analysis was performed on a derivatograph of R. Paulik, I. Paulik, L. Erdey system of MOM (Budapest) firm. The samples were heated at a rate of $10{ }^{\circ} \mathrm{C}$ per minute to a temperature of $1000{ }^{\circ} \mathrm{C}$. Electron microscopy was carried out using a REMMA $102 \mathrm{M}$ scanning electron microscope (Ukraine).

The study of the immobilization properties of alkali concrete was carried out according to the European methodology (EN 12457-1:2002, Part 1), which consists in measuring the concentrations of heavy metal ions in a dispersion medium after a long dynamic interaction of artificial stone with distilled water.

The radiological properties of alkaline concrete using red mud were measured using CANBERRA germanium detectors according to European procedures.

The determination of physical and mechanical and special (weather resistance, strength, frost resistance, carbonization, corrosion resistance) properties of the investigated concrete mixtures and concretes were carried out according to standard methods in accordance with current standards.

The frost resistance of concrete samples was determined according to GDSTU B.V.2.7-49-96 according to the third accelerated method. The freezing temperature of concrete samples was $(-45 \pm 5){ }^{\circ} \mathrm{C}$. As criteria for assessing the frost resistance of concrete, loss of strength, weight loss, and peeling of the concrete surface were determined. 
The study of shrinkage deformation of alkaline concrete was carried out according to DSTU B.V.2.7-216:2009. The tests were carried out on specimen-cubes measuring $10 \times 10 \times 10 \mathrm{~cm}$. When determining the indicators of shrinkage deformation, the following operations were performed:

- before the test, the samples were examined, the existing defects were eliminated, individual speeches on the faces were removed with an emery stone, the measured linear dimensions;

- before testing, samples were kept in the laboratory for at least 2 hours.

On the lateral surfaces of the samples, central lines were marked for the installation of instruments for measuring deformation and centering of samples. Alignment centers for longitudinal and transverse deformations of the samples were flashed along the central lines. The strain measurement base should be 2.5 times or more larger than the largest aggregate grain size and should be at least $50 \mathrm{~mm}$ when using strain gauges and $100 \mathrm{~mm}$ when using other strain measuring instruments. The longitudinal strain measurement base did not exceed $2 / 3$ of the sample height and was located at the same distance from its ends, which corresponds to the requirements of DSTU B.V.2.7-216:2009.

\section{Research results}

6.1. The study of changes in the physico-mechanical properties of alkali concrete in time. The main property of traditional and alkaline concrete is that they are able to improve the strength characteristics over time by continuing the processes of cement hydration and compaction of the structure of artificial stone.
To determine the physic-mechanical properties of concrete over time, the optimal compositions of alkaline concrete based on red mud were selected and their compressive strength for 90,180 , and 360 days of hardening was determined under normal conditions. The results of the studies are shown in Fig. 1. Compositions of concrete $1 \mathrm{~B}-5 \mathrm{~B}$ are given in Table 1.

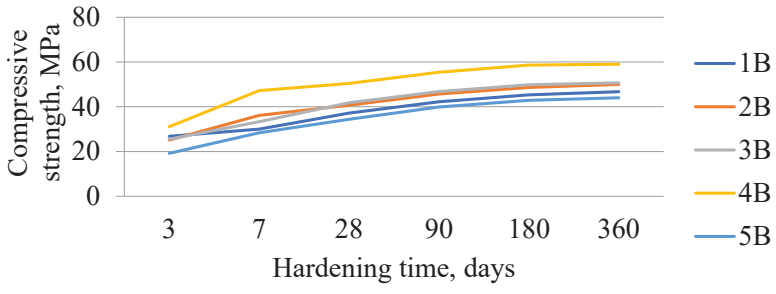

Fig. 1. The strength characteristics of concrete (Table 1) based on red mud in time

Based on the obtained results, it can be argued that the developed alkaline concrete with a high content of red mud (up to $40 \%$ of the total mass) is able to increase strength characteristics over time. This indicates the unfinished physicochemical processes taking place in the cement matrix of the conglomerate.

6.2. Study of frost resistance. Frost resistance of concrete samples was determined according to DSTU B.V.2.7.-47-96 «Concrete. Methods for determining frost resistance. General requirements» according to the third accelerated method when samples are saturated in a $5 \% \mathrm{NaCl}$ solution.

The study of concrete based on red mud was carried out in optimized warehouses with different contents of red mud. The test results are shown in Table 2 .

Composition of heavy alkaline concrete using red mud

Table 1

\begin{tabular}{|c|c|c|c|c|c|c|c|c|c|c|c|c|}
\hline \multirow{3}{*}{ Marking } & \multicolumn{11}{|c|}{ Concrete composition, $\mathrm{kg} / \mathrm{m}^{3}$} & \multirow{3}{*}{$55, \mathrm{~cm}$} \\
\hline & \multicolumn{5}{|c|}{ Cement composition } & \multirow{2}{*}{$\begin{array}{l}\text { red } \\
\text { mud }\end{array}$} & \multicolumn{4}{|c|}{ Aggregate } & \multirow{2}{*}{$\mathrm{H}_{2} \mathrm{O}$} & \\
\hline & slum & $\mathrm{PC}$ & ash & MS & LST & & sand & granite screenings & fraction $5 . .10 \mathrm{~mm}$ & fraction $10 . . .20 \mathrm{~mm}$ & & \\
\hline $1 \mathrm{~B}$ & 400 & 11.5 & 23.1 & 46.2 & 2.8 & 885 & 187 & 187 & 187 & 187 & 307 & 5 \\
\hline $2 B$ & 390 & 11.3 & 22.7 & 45.5 & 2.8 & 655 & 239 & 239 & 239 & 239 & 267 & 6 \\
\hline 3B & 370 & 4.1 & 16.4 & 16.4 & 4.1 & 210 & 370 & 370 & 370 & 370 & 200 & 9 \\
\hline $4 \mathrm{~B}$ & 414 & 4.8 & 19.2 & 38.5 & 4.8 & 318 & 330 & 330 & 330 & 330 & 200 & 7 \\
\hline $5 B$ & 388 & 16.0 & 17.6 & 35.2 & 1.9 & 861 & 136 & 136 & 136 & 136 & 323 & 9 \\
\hline
\end{tabular}

Note: PГ - Portland cement; MS - metasilicate; LST - lignosulfonates; 55 - shrinkage sediment of concrete mixture

Table 2

Frost resistance of alkaline concrete using red mud

\begin{tabular}{|c|c|c|c|c|c|c|c|c|}
\hline Marking & Red mud, \% & $55, \mathrm{~cm}$ & $\Delta m, \%$ & $R_{C \text { before saturation, } \mathrm{MPa}}$ & $R_{C \text { after saturation, } \mathrm{MPa}}$ & $\begin{array}{c}\text { Loss of } \\
\text { strength, \% }\end{array}$ & $\begin{array}{c}\text { Water absorption } \\
\text { by weight, \% }\end{array}$ & $\begin{array}{c}\text { Frost resistance } \\
\text { class }\end{array}$ \\
\hline 1B & 40 & 5 & -0.21 & 37.2 & 34.4 & 7.52 & 8.8 & - \\
\hline 2B & 30 & 6 & -0.04 & 40.7 & 39.2 & 3.68 & 7.9 & - \\
\hline 3B & 10 & 9 & 0.00 & 41.8 & 42.0 & -0.47 & 5.0 & F75 \\
\hline 4B & 15 & 7 & -0.08 & 50.4 & 52.8 & -4.80 & 5.7 & F100 \\
\hline 5B & 40 & 9 & -0.13 & 34.4 & 32.2 & 6.39 & 8.6 & - \\
\hline
\end{tabular}

Note: concrete compositions are given in Table $1 ; \Delta m$ - the change in mass of the sample; $R_{c}-$ the compressive strength; 55 - shrinkage sediment of concrete mixture 
An analysis of the results shows that the use of up to $40 \%$ of red mud in concrete (compositions $1 \mathrm{~B}$ and $5 \mathrm{~B}$ ) negatively affects its frost resistance. This is indicated by strength losses exceeding the standard conditions $(<5 \%$ of the total volume). Visual inspection revealed peeling of the concrete surface after the first freeze-thaw cycle. The reason for this is a rather significant increase in the amount of water in the concrete mix, increases its mobility and forms capillary (open) time (Table 3). Reducing the content of red mud to $10 \%$ (by weight of concrete) reduces water demand and allows to obtain frost-resistant concrete of class F75 by increasing conditionally closed pores ( $4 \%$ of the total volume).

Increasing the amount of red mud (composition 4B) up to $15 \%$ at a constant water-cement ratio (W/C) reduces the mobility of the concrete mix from 9 to $7 \mathrm{~cm}$ and increases the volume of conditionally closed pores to $6.7 \%$, which makes it possible to achieve the frost resistance class F100.

Table 3

The study of porosity of alkaline concrete using red mud

\begin{tabular}{|c|c|c|c|c|c|}
\hline Marking & $\begin{array}{c}\text { The amount } \\
\text { of red mud in } \\
\text { the concrete } \\
\text { composition, } \\
\%\end{array}$ & $\begin{array}{c}\text { 55, } \\
\mathrm{cm}\end{array}$ & $\begin{array}{c}\text { Total } \\
\text { (integral) } \\
\text { pore } \\
\text { volume, } \\
P_{1,} \%\end{array}$ & $\begin{array}{c}\text { The volume } \\
\text { of capillary } \\
\text { (open) pores, } \\
P_{C,} \%\end{array}$ & $\begin{array}{c}\text { The volume } \\
\text { of conditio- } \\
\text { nally closed } \\
\text { pores, } \\
P_{C l}, \%\end{array}$ \\
\hline 1B & 40 & 5 & 18.3 & 17.8 & 0.5 \\
\hline 2B & 30 & 6 & 18.0 & 16.4 & 1.6 \\
\hline 3B & 10 & 9 & 15.1 & 11.1 & 4.0 \\
\hline 4B & 15 & 7 & 18.8 & 12.1 & 6.7 \\
\hline 5B & 40 & 9 & 18.6 & 16.9 & 1.6 \\
\hline
\end{tabular}

Note: concrete compositions are given in Table 1

The results of studies of frost resistance and porosity of concrete using red mud show that the frost resistance of concrete depends on the volume of open and conditionally closed pores. Obtaining artificial stone with high frost resistance is possible with an increase in the number of conditionally closed pores (the use of air-entraining additives) and a decrease in the amount of water needed to prepare the concrete mixture. Preservation of the rheological properties of alkaline concrete is possible by selecting additives of plasticizers.

6.3. Study of natural shrinkage strains. The main reason for the shrinkage of alkaline binders is the volumetric changes in the gel of the cement stone when it dries, which depend on the mineralogical composition of the system, the fineness of the grinding of cement, the type of alkaline component, conditions and time of hardening. Comparative characteristics of shrinkage of the considered alkaline concrete are shown in Fig. 2.

Thus, the developed concretes based on red mud have greater shrinkage rates (up to $-0.6 \mathrm{~mm} / \mathrm{m}$ ) than slagalkali concrete (up to $0.33 \mathrm{~mm} / \mathrm{m}$ ), which is due to their greater water demand and high free water content in the system. However, when using red mud in concrete, up to $15 \%$ of the total mass, shrinkage deformations decrease and amount to $0.42 \mathrm{~mm} / \mathrm{m}$ for 60 days of hardening.

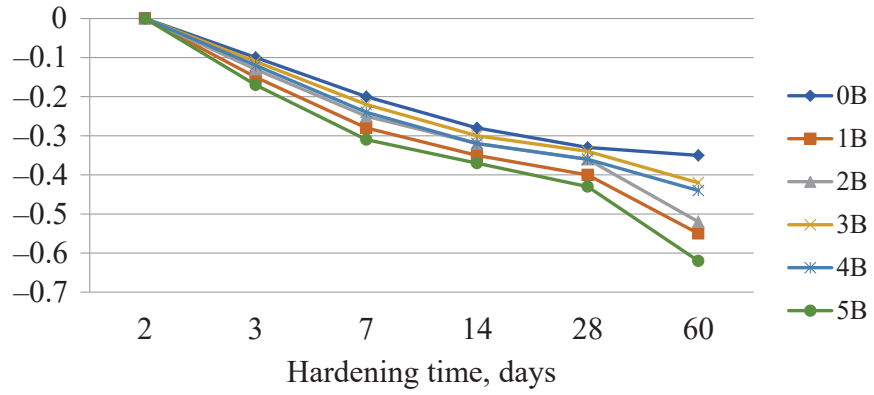

Fig. 2. Change in shrinkage of alkaline concrete using red mud: BO - composition of comparison, concrete compositions 1B-5B are given in Table 1

6.4. Study of the carhonization process. The carbonation of concrete is considered to be the reaction of the phases of cement stone with carbon dioxide. In this case, the phases turn into carbonate and other reaction products, which lead to a change in the structure of the cement stone and a decrease in the $\mathrm{pH}$ in the pore fluid.

The carbonization process can be considered in two aspects: positive and negative. A positive consequence of this structural transformation is the compaction of cement stone and concrete based on it, a decrease in the total pore volume in the structure by $20 . .28 \%$, which increases the physic-mechanical and special properties of such materials.

A negative consequence of carbonation is a decrease in the $\mathrm{pH}$ of artificial cement stone and concrete. It is worth noting that this process is potentially dangerous for concrete structures reinforced with steel reinforcement. For the remaining concrete structures, the carbonization process of the structure, or chemical aging due to carbonization, does not pose a particular danger.

In addition, it is worth noting that for alkaline cements in general, and alkaline cements using related products of the cement industry in particular, it is possible to form a certain amount of calcium carbonates as a result of hydration reactions of the main components of the binder. Therefore, such a process has nothing to do with the contact of the cement phases again with carbon dioxide and cannot be regarded as carbonization of concrete in the traditional sense of the term. For alkaline systems, the initial formation of calcium carbonate leads to a densification of the structure and a decrease in the pore space in the structure of cement and concrete, that is, it plays a positive role.

Traditionally, various methods are used to assess the depth of carbonization: X-ray diffractometry, infrared spectroscopy, microscopy, differential thermal analysis, chemical analysis, or using indicators. However, for alkaline cements, the application of the vast majority of the proposed methods is not advisable because of the impossibility of such methods to separate the carbonate phases formed during the hydration of cement components among themselves from carbonization products in the traditional sense of this process.

Therefore, the method for the use of indicators should be recognized as the most effective for studying the carbonization of alkaline concrete based on fuel ashes.

Determination of the thickness of the carbonized concrete layer based on alkaline cement is determined by the method, which consists in splitting the concrete and 
wetting the cleaved surface with a $0.1 \%$ phenolphthalein alcohol solution. For the carbonized concrete layer, in this case, the surface color will not change, while for a concrete surface with a high concentration of alkalis in the pore liquid, the surface is painted a bright crimson color.

Samples of the studied concrete were kept in air-dry conditions (indoor temperature of $20 \pm 2{ }^{\circ} \mathrm{C}$ and relative humidity of 65-70\%). That is, in such conditions that are most dangerous from the point of view of carbonization during the actual operation of structures.

The results of studies of alkali concrete carbonization using red mud are shown in Fig. 3.

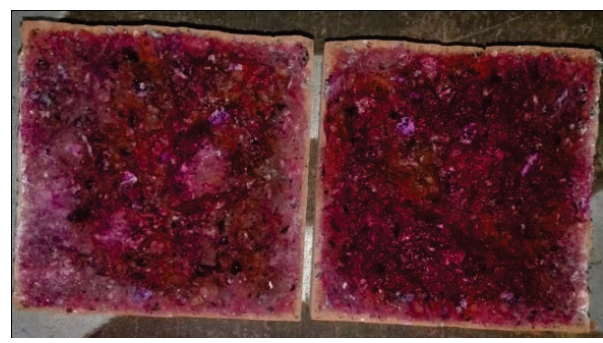

$a$

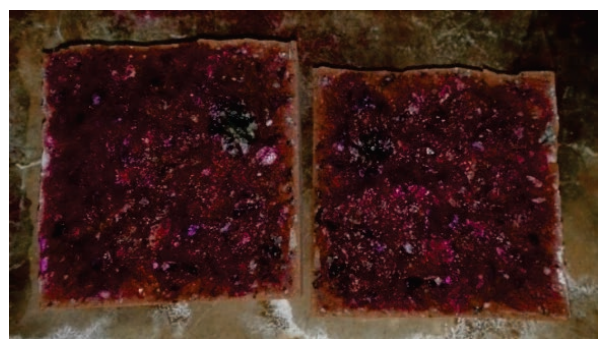

Fig. 3. Photos of the surface of the cleaved alkaline concrete using red mud: $a-10 \%$ by weight of concrete; $b-15 \%$ by weight of concrete

The study of the $\mathrm{pH}$ of the concrete based on alkaline cement using red mud is carried out using a traditional indicator - litmus paper. An aqueous $10 \%$ extract from milled concrete samples is also investigated at the age of 28 and 90 days of concrete hardening. The results show a stable preservation of the high alkalinity of the alkaline concrete medium (the $\mathrm{pH}$ value is $13.2 \ldots 13.5$, regardless of the type of cement used).

The results of a study of the carbonation of concrete based on alkaline cements using red mud show that the carbonized layer at the age of 90 days is $2 \mathrm{~mm}$, confirming traditional ideas about the mechanisms of hydration of alkaline cements. Indeed, such systems are characterized by the complete absence of free calcium hydroxide, which is the main carrier of carbonation of artificial stone, in the composition of hydration products.

The prediction of the longevity of alkaline cements in terms of carbonization can also be carried out by assessing the stability of the reinforcement in the structure against corrosion. To simplify the calculation, it is assumed that the structure loses its properties when the carbonation depth is reached, which corresponds to the protective layer of concrete. After reaching this state, corrosion and destruction of the working reinforcement begins.

For the calculation, the maximum depth of carbonation of concrete in the samples is taken. The thickness of the protective layer to the reinforcement in the structure is
$20 \mathrm{~mm}$. The results of research and calculation of the duration of the protective effect of concrete are given in Table 4.

Table 4

Effective $\mathrm{CO}_{2}$ diffusion coefficient and duration of protective action of alkaline concrete using red mud

\begin{tabular}{|l|c|c|c|}
\hline $\begin{array}{c}\text { Type of } \\
\text { concrete }\end{array}$ & $\begin{array}{c}\text { The maximum } \\
\text { depth of } \\
\text { concrete car- } \\
\text { bonation, cm }\end{array}$ & $\begin{array}{c}\text { Effective dif- } \\
\text { fusion coef- } \\
\text { ficient of } \mathrm{CD}_{2}, \\
\mathrm{D}, \mathrm{cm}^{2} / \mathrm{s}\end{array}$ & $\begin{array}{c}\text { The thickness of the carbo- } \\
\text { nized layer after } 50 \text { years of } \\
\text { operation, at a concentration } \\
\text { of } 0.03 \% \mathrm{CO}_{2}\end{array}$ \\
\hline $\begin{array}{l}\text { Red } \\
\text { mud-based } \\
\text { concrete }\end{array}$ & 0.2 & $4.2 \cdot 10^{-4}$ & \multicolumn{2}{|c|}{2.85} \\
\hline
\end{tabular}

An analysis of the results show that alkaline concrete based on red mud has a diffusion coefficient of $4.2 \cdot 10^{-4}$, which ensures the durability of reinforced concrete structures for a period of 50 years with a protective layer thickness of more than $3 \mathrm{~cm}$.

6.5. Study of immohilizing ability. A study of the reliability of immobilization of heavy metals in alkaline concrete using red mud was carried out according to GB 5085.3-2007. For the manufacture of samples are used concrete compositions containing up to $40 \%$ of red mud (by weight of concrete). This will determine the reliability of the content of heavy metals in the structure of the stone with the maximum filling of its care. The test results are given in Table 5 .

Table 5

Immobilizing ability of alkaline concrete using red mud

\begin{tabular}{|c|c|}
\hline Compound & Concentration of ion compounds, (mg/l) \\
\hline Lead, $\mathrm{Pb}$ & 0.10 \\
\hline Chrome $\mathrm{Cr}$ & 0.15 \\
\hline Arsenic, As & 0.05 \\
\hline
\end{tabular}

The obtained results comply with the requirements of the standard (GB 5085.3-2007) and indicate that the developed concrete is environmentally friendly. This allows to expand the use of alkaline concrete with a high content of red mud for products or structures exposed to atmospheric influences.

According to SanPiN 2.1.4.1074-01, the resulting dispersion medium does not meet the requirements for drinking water in terms of chromium and lead $(0.05 \mathrm{mg} / \mathrm{l}$ and $0.03 \mathrm{mg} / \mathrm{l}$, respectively). However, according to GOST 23732-2011 (EN 1008:2002, NEQ and EN 206-1:2000, NEQ), the resulting solution meets the requirements of industrial water and can be used for the manufacture of concrete mixtures and solutions, confirming its environmental safety.

6.6. Study of radiological properties. Determination of the radiological properties of alkaline concrete is carried out according to the methods specified in [11, 12]. The content of red mud in concrete was up to $40 \%$ by weight of concrete (per $1 \mathrm{~m}^{3}$ ) to determine the effective total specific activity $\left(A_{e f f}\right)$ of natural radionuclides. The tests were carried out on the 28th day of hardening of samples under normal conditions according to the standard GB 6566-2010. The results of radiological studies are given 
in Table 6. The active concentrations of the components of alkaline concrete are given in Tables 7,8 .

Table 6

The results of radiological studies of alkaline concrete using red mud

\begin{tabular}{|c|c|c|c|}
\hline \multicolumn{2}{|c|}{ The specific activity of radionuclides $\left(\mathrm{Bq} \cdot \mathrm{kg}^{-1}\right)$} & Classification \\
\hline Ba-226 & Th-232 & $\mathrm{K}-40$ & General construction \\
material
\end{tabular}

Table 7

Active concentrations in $\mathrm{Bq} / \mathrm{kg}$ (dry material) of gamma radiation of the main raw materials

\begin{tabular}{|c|c|c|c|c|c|c|}
\hline \multirow{2}{*}{$\begin{array}{c}\text { Sam- } \\
\text { ple }\end{array}$} & \multicolumn{5}{|c|}{$\mathrm{U}$ series } & ${ }^{235} \mathrm{U}$ \\
\cline { 2 - 7 } & ${ }^{234} \mathrm{Th}$ & ${ }^{234 \mathrm{~m}} \mathrm{~Pa}$ & ${ }^{214} \mathrm{~Pb}$ & ${ }^{214} \mathrm{Bi}$ & ${ }^{210} \mathrm{~Pb}$ & ${ }^{235} \mathrm{U}$ \\
\hline $\begin{array}{c}\text { Red } \\
\text { mud }\end{array}$ & $83 \pm 17$ & $84 \pm 11$ & $75 \pm 5$ & $73 \pm 5$ & $91 \pm 19$ & $3.5 \pm 0.4$ \\
\hline 5lag & $103 \pm 17$ & $98 \pm 13$ & $99 \pm 6$ & $96 \pm 6$ & $<5$ & $4.6 \pm 0.4$ \\
\hline $\begin{array}{c}\text { PC } \\
\text { I-500 }\end{array}$ & $36 \pm 6$ & $33 \pm 5$ & $32 \pm 2$ & $30 \pm 2$ & $22 \pm 6$ & $1.6 \pm 0.2$ \\
\hline $\begin{array}{c}\text { River } \\
\text { sand }\end{array}$ & $2.6 \pm 1.1$ & $<10$ & $3.0 \pm 0.2$ & $3.0 \pm 0.3$ & $2.9 \pm 0.8$ & $0.18 \pm 0.04$ \\
\hline
\end{tabular}

Table 8

Active concentrations in $\mathrm{Bq} / \mathrm{kg}$ (dry material) of gamma radiation of the main raw materials (another series)

\begin{tabular}{|c|c|c|c|c|c|c|}
\hline \multirow{2}{*}{$\begin{array}{c}\text { Sam- } \\
\text { ple }\end{array}$} & \multicolumn{5}{|c|}{${ }^{232} \mathrm{Th}$ series } & ${ }^{40} \mathrm{~K}$ \\
\cline { 2 - 7 } & ${ }^{228} \mathrm{Ac}$ & ${ }^{224} \mathrm{Ra}$ & ${ }^{212} \mathrm{~Pb}$ & ${ }^{212} \mathrm{Bi}$ & ${ }^{208} \mathrm{Tl}$ & ${ }^{40} \mathrm{~K}$ \\
\hline $\begin{array}{c}\text { Red } \\
\text { mud }\end{array}$ & $191 \pm 12$ & $188 \pm 13$ & $192 \pm 13$ & $189 \pm 20$ & $193 \pm 12$ & $39 \pm 4$ \\
\hline 5lag & $52 \pm 4$ & $53 \pm 4$ & $52 \pm 4$ & $49 \pm 9$ & $52 \pm 4$ & $119 \pm 11$ \\
\hline $\begin{array}{c}\text { PC } \\
\text { I-500 }\end{array}$ & $19.4 \pm 1.5$ & $18.5 \pm 1.5$ & $19.2 \pm 1.3$ & $18.0 \pm 3.2$ & $18.9 \pm 2.0$ & $231 \pm 20$ \\
\hline $\begin{array}{c}\text { River } \\
\text { sand }\end{array}$ & $2.7 \pm 0.3$ & $2.8 \pm 0.5$ & $2.8 \pm 0.2$ & $<4$ & $2.7 \pm 0.3$ & $64 \pm 6$ \\
\hline
\end{tabular}

According to the analysis of the obtained results, it can be concluded that alkaline concrete samples meet the requirements of GB 6566-2010 and relate to general construction materials. However, according to DBN B.1.4-2.01-97, the classification of building materials by specific activity of radionuclides is classified:

- I class - $A_{e f}<370 \mathrm{~Bq} / \mathrm{kg}^{-1}$ - all types of construction without restrictions;

- II class - $A_{e f}<740 \mathrm{~Bq} / \mathrm{kg}^{-1}$ - industrial and road construction within settlements;

- III class $-A_{e f}<1350 \mathrm{~Bq} / \mathrm{kg}^{-1}$ - industrial and road construction outside the settlements.

So, alkaline concrete using red mud in an amount up to $40 \%$ (by weight of concrete) belongs to class I according to the classification of building materials and can be used for all types of construction without restrictions.

However, according to the European Directive 2013/59, the determination of the radiological properties of building materials is carried out using the active concentration index (ACI). For all building materials, it should be less than 1 . In case the ACI is more than 1, all structural design features must be taken into account.

Since measurements are carried out to determine the natural isotope effect, $235 \mathrm{U}$ values will be considered as a quality control tool. Considering the decay chains of $238 \mathrm{U}$, from $238 \mathrm{U}$ to $214 \mathrm{Bi}$, the active concentration of slag radionuclides is equal to or slightly higher than the activity of radionuclides in red mud. However, for $210 \mathrm{~Pb}$ slag, the equilibrium between $210 \mathrm{~Pb}$ and radionuclides from the $238 \mathrm{U}$ series is absent, and for red mud it is maintained. The activity concentrations for both red mud and slag are 20-40 times higher than for sand and 2-4 times higher than for I-500 PC.

For the 232Th series, secular equilibrium is present in all raw materials. The active concentration for individual radionuclides in the red mud is 3.5 times greater than the active concentration of radionuclides in the slag. For the $40 \mathrm{~K}$ chain, the active concentration of slag radionuclides is 3 times higher than for red mud. 137Cs are not detected in any of the raw materials.

\section{SWOT analysis of research results}

Strengths. A positive aspect of these studies is the identification of important functional properties of the new material, namely alkaline concrete with a high content of red mud. This allows to expand the range of building materials and to improve both the environmental and economic conditions of the country. Moreover, given that the use of technogenic raw materials significantly reduces the cost of production, it can be argued about the economic feasibility of using products based on alkaline concrete using red mud.

Weaknesses. In the process of conducting research, some weaknesses are noted when working with red mud. First of all, it is its high specific surface, which does not allow plasticizing the concrete mixture. Therefore, in the manufacture of hard mixtures, it is necessary to add a large amount of water, the performance of concrete has a bad effect on strength.

Opportunities. The research results confirm that disposing of red mud by using it as a raw material for concrete is a safe and effective method for solving this problem. Thus, alkaline concrete with high red mud content opens up new opportunities for the entire industry, especially if to take into account the fact that it is a new material and has no analogues.

Threats. As for the negative impact on the object of research of external factors, then there is a fairly expensive operation - drying the mud. After all, to store red mud in slurries, it is moistened to a moisture content of $100 \%$. However, the positive effect of the disposal of this waste compensates for these costs.

\section{Conclusions}

1. A study of the increase in strength over time of alkaline concrete using red mud is made. For this, the optimal compositions of alkali concrete based on red mud were selected and their compressive strength for 90,180 and 360 days of hardening was determined under normal conditions. Based on the obtained results, it can be argued that the developed alkaline concrete with a high content of red mud (up to $40 \%$ of the total mass) is able to increase strength characteristics over time.

2. The study of concrete based on red mud was carried out in optimized compositions with different contents of red mud. An analysis of the results shows that the use 
of up to $40 \%$ of red mud in the composition of concrete negatively affects its frost resistance, since the loss in strength exceeds the standard conditions. An increase in the amount of red mud to $15 \%$ with a constant $\mathrm{W} / \mathrm{C}$ reduces the mobility of the concrete mix from 9 to $7 \mathrm{~cm}$ and increases the volume of conditionally closed pores to $6.7 \%$, which makes it possible to achieve the frost resistance class F100.

3. A study is conducted to determine the shrinkage strain of alkaline concrete using red mud. Thus, the developed concretes based on red mud have greater shrinkage rates (up to $-0.6 \mathrm{~mm} / \mathrm{m}$ ) than slag-alkali concrete (up to $0.33 \mathrm{~mm} / \mathrm{m}$ ), which is due to their greater water demand and high free water content in the system.

4. The study of the $\mathrm{pH}$ of the concrete based on alkaline cement using red mud was carried out using a traditional indicator - litmus paper. An aqueous $10 \%$ extract from milled concrete samples was also investigated at the age of 28 and 90 days of concrete hardening. The results show a stable preservation of the high alkalinity of the alkaline concrete medium (the $\mathrm{pH}$ value is $13.2 \ldots 13.5$, regardless of the type of used cement). The results of a study of the carbonation of concrete based on alkaline cements using red mud show that the carbonized layer at the age of 90 days is $2 \mathrm{~mm}$, confirming traditional ideas about the mechanisms of hydration of alkaline cements. Indeed, such systems are characterized by the complete absence of free calcium hydroxide, which is the main carrier of carbonation of artificial stone, in the composition of hydration products.

5. The radiological properties of alkaline concrete are determined in an alkaline concrete warehouse using red mud in an amount of up to $40 \%$ by weight of concrete (per $1 \mathrm{~m}^{3}$ ). The tests were carried out on the $28^{\text {th }}$ day of hardening of samples under normal conditions according to the standard GB 6566-2010. The results show that alkaline concrete using red mud in an amount of up to $40 \%$ (by weight of concrete) belongs to class I according to the classification of building materials and can be used for all types of construction without restrictions.

\section{References}

1. Kumar, S., Kumar, R., Bandopadhyay, A. (2006). Innovative methodologies for the utilisation of wastes from metallurgical and allied industries. Resources, Conservation and Recycling, 48 (4), 301-314. doi: http://doi.org/10.1016/j.resconrec.2006.03.003

2. Meshin, V. V. (1999). Raboty Nikolaevskogo glinozemnogo zavoda po ispolzovaniiu krasnykh shlamov. Sostoianie, problemy $i$ napravleniia ispolzovaniia v narodnom khoziaistve krasnogo shlama. Nikolaev, 7-9.

3. Utkov, V. A., Bytkin, V. V., Korobov, V. I. et. al. (1999). Rezultaty povedennykh promyshlennykh ispytanii po piro-i gidrologicheskoi kompleksnoi pererabotki i ispolzovaniiu tovarnogo krasnogo shlama («Fakrinta») v aglodomennom proizvodstve chernoi metallurgii. Sostoianie, problemy i napravleniia ispolzovaniia v narodnom khoziaistve krasnogo shlama. Nikolaev, 30-34.

4. Kolesnik, N. F., Prikhodko, E. V., Akhmatov, Iu. S., Nesterenko, A. M., Pirogova, E. K. (1988). Osobennosti processa polucheniia sazhistogo zheleza s ispolzovaniem koloshnikovykh gazov metallurgicheskikh agregatov. Metallurgicheskaia i gornorudnaia promyshlennost, 2, 8-11.

5. Kolesnik, N. F., Sorkin, L. P., Priluckii, O. V. (1990). Poluchenie dispersnikh metallouglerodnykh kompozicii s ispolzovaniem koloshnikovykh gazov zakrytykh ferrosplavnykh pechei. Izvestiia vysshikh uchebnykh zavedenii. Chernaia metalurgiia, 5, 39-46.

6. Korneev, V. I., Suss, A. G., Cekhovoi, A. I. (1991). Krasnye shlamy - svoistva, skladirovanie, primenenie. Moscow: Metallurgiia, 144.

7. Kirichenko, A. G., Nasekan, Iu. P., Kolesnik, N. F. (2011). Vliianie granulometricheskogo sostava krasnogo shlama na kinetiku nauglerozhivaniia. Vestnik Nac. tekhn. un-ta «KHPI». Temat. vyp.: Novye resheniia v sovremennykh tekhnologiiakh, 33, 7-11.

8. Makarov, V., Vasileva, T., Makarov, D., Alkaceva, A. (2005) Potencialnaia ekologicheskaia opasnost vyvedennykh iz ekspluatacii khranilisch khvostov obogascheniia medno-nikelevykh rud. Khimiia v interesakh ustoichivogo razvitiia, 13, 85-93.

9. Galeckii, L. S., Bent, O. I., Makogon, V. F. et. al. (1994) Perspektivy polucheniia cvetnykh $i$ redkikh metallov iz tekhnogennykh otkhodov na Ukraine. Kyiv: Znanie, 29

10. Tischenko, G. P., Moisenko, N. Iu., Zhuravlev, V. S. et. al. (1991). Utilizaciia promyshlennykh otkhodov. Obz. inf. Ser. Aktualnye voprosy khim. nauki i tekhnolog. $i$ okhrany okruzh. sredy, 3, 1-84.

11. Krivenko, P., Kovalchuk, O., Pasko, A., Croymans, T., Hult, M. Lutter, G. et. al. (2017). Development of alkali activated cements and concrete mixture design with high volumes of red mud. Construction and Building Materials, 151, 819-826. doi: http:// doi.org/10.1016/j.conbuildmat.2017.06.031

12. Alonso, M. M., Pasko, A., Gascó, C., Suarez, J. A., Kovalchuk, O., Krivenko, P., Puertas, F. (2018). Radioactivity and Pb and $\mathrm{Ni}$ immobilization in SCM-bearing alkali-activated matrices. Construction and Building Materials, 159, 745-754. doi: http:// doi.org/10.1016/j.conbuildmat.2017.11.119

Boiko Olha, Postgraduate Student, Scientific-Research Institute for Binders and Materials named after V. D. Glukhovsky, Kyiv National University of Construction and Architecture, Ukraine, e-mail olia.bojkoyt@gmail.com, ORCID: http://orcid.org/0000-00017521-0166

Zozulynets Viktoria, Postgraduate Student, Scientific-Research Institute for Binders and Materials named after V. D. Glukhovsky, Kyiv National University of Construction and Architecture, Ukraine, e-mail: zozulinets555@gmail.com, ORCID: http://orcid.org/00000002-8066-2033

Ivanychko Vasyl, Postgraduate Student, Scientific-Research Institute for Binders and Materials named after V. D. Glukhovsky, Kyiv National University of Construction and Architecture, Ukraine, e-mail: ivanychko32@gmail.com, ORCID: http://orcid.org/00000002-4384-6490

Kovalchuk Oleksandr, PhD, Senior Researcher, Scientific-Research Institute for Binders and Materials named after V. D. Glukhozsky, Kyiv National University of Construction and Architecture, Ukraine, e-mail: kovalchuk.oyu@gmail.com, ORCID: http://orcid.org/00000001-6337-0488 